Communications in Physics, Vol. 27, No. 3 (2017), pp. 193-203

DOI:10.15625/0868-3166/27/3/10034

\title{
RADIATION DOSE ESTIMATION OF CEMENT SAMPLES USED IN LAO PDR
}

\author{
SONEXAY XAYHEUNGSY ${ }^{a, b, \dagger}$, LE HONG KHIEM ${ }^{b, c}$, AND LE DAI NAM ${ }^{b, c}$ \\ ${ }^{a}$ Faculty of Science, The National University of Laos, Lao PDR \\ ${ }^{b}$ Graduate University of Science and Technology, Vietnam Academy of Science and Technology, \\ 18 Hoang Quoc Viet, Cau Giay, Hanoi, VietNam \\ ${ }^{c}$ Institute of Physics, Vietnam Academy of Science and Technology, 10 DaoTan, Ba Dinh, Hanoi, \\ VietNam \\ $\dagger$ E-mail: sonexaysy@gmail.com
}

Received 24 September 2017

Accepted for publication 23 October 2017

Published 02 November 2017

\begin{abstract}
The natural radioactivity due to the presence of ${ }^{226} \mathrm{Ra},{ }^{232} \mathrm{Th}$ and ${ }^{40} \mathrm{~K}$ radionuclides in Lao PDR cements was measured for the first time using a gamma-spectrometry with HPGe detector. Two different types of cement produced by 4 local cement companies in Lao PDR have been investigated. The specific radioactivity of ${ }^{226} \mathrm{Ra},{ }^{232} \mathrm{Th}$ and ${ }^{40} \mathrm{~K}$ in the investigated samples ranged from $24.83 \pm 1.18$ to $54.39 \pm 5.90 \mathrm{~Bq} \mathrm{~kg}{ }^{-1}$ with a mean of $37.76 \pm 10.71 \mathrm{~Bq} \mathrm{~kg}^{-1}, 6.63$ \pm 1.59 to $21.17 \pm 0.48 \mathrm{~Bq} \mathrm{~kg}^{-1}$ with a mean of $13.77 \pm 5.85 \mathrm{~Bq} \mathrm{~kg}^{-1}$ and $43.28 \pm 7.68$ to 168.70 $\pm 3.34 \mathrm{~Bq} \mathrm{~kg}^{-1}$ with a mean of $116.07 \pm 47.50 \mathrm{~Bq} \mathrm{~kg}$, respectively. The radium equivalent activity $\left(R a_{e q}\right)$, the gamma-index, the external and internal hazard indices, Absorb Dose Rate in Air (D) and Annual Effective Dose Equivalent (AEDE) were estimated for the radiation hazard of the natural radioactivity in all cement samples. The obtained results were compared with the corresponding values for cement of different countries. The calculated $R a_{e q}$ values of Lao PDR samples are lower than the limit of $370 \mathrm{~Bq} \mathrm{~kg}{ }^{-1}$ set for building materials. The mean indoor absorbed dose rate is slightly lower than the population-weighted average of $84 n G y h^{-1}$ while the corresponding effective dose was $79 \%$ less than the dose of $1 \mathrm{mSv} y^{-1}$. The results obtained in this study show no significant radiological hazards arising from using Lao PDR cement for construction of houses.
\end{abstract}

Keywords: Gamma-ray spectrometer, natural radionuclides, cement, Laos PDR, radiation hazards. Classification numbers: 91.65.Dt; 87.55.N-.

(C)2017 Vietnam Academy of Science and Technology 


\section{INTRODUCTION}

Historical antecedents of studies conducted on natural radioactivity have established that the presence of uranium $\left({ }^{238} \mathrm{U}\right)$ and thorium $\left({ }^{232} \mathrm{Th}\right)$ series and potassium $\left({ }^{40} \mathrm{~K}\right)$ in various materials constitute potential exposure to the global population. Although building materials act as a source of radiation to the inhabitants in their dwellings, they also have the role of a shield against outdoor radiation [1]. In the ${ }^{238} \mathrm{U}$ series, the decay chain segment starting from radium $\left({ }^{226} \mathrm{Ra}\right)$ is the most important in terms of radiological hazard and, therefore, reference is often made to ${ }^{226} \mathrm{Ra}$ instead of ${ }^{238} \mathrm{U}$. The external exposure is caused by direct gamma radiation while the inhalation of radioactive inert gases of radon $\left({ }^{222} \mathrm{Rn}\right.$, a daughter product of $\left.{ }^{226} \mathrm{Ra}\right)$ and thoron $\left({ }^{220} \mathrm{Rn}\right.$, a daughter product of ${ }^{224} \mathrm{Ra}$ ), and their short-lived secondary products lead to the internal exposure of the respiratory tract to alpha particles. The specific activities of ${ }^{226} \mathrm{Ra},{ }^{232} \mathrm{Th}$ and ${ }^{40} \mathrm{~K}$ in the building raw materials and products mainly depend on geological and geographical conditions as well as geochemical characteristics of these materials. The worldwide average specific activities of ${ }^{226} \mathrm{Ra}$, ${ }^{232} \mathrm{Th}$ and ${ }^{40} \mathrm{~K}$ in the earth's crust are estimated at 32,45 and $420 \mathrm{~Bq} \mathrm{~kg}^{-} 1$, respectively [2]. In order to assess the radiological hazards to human health, it is important to study the radioactivity levels emitted by these materials. The data obtained from that study are essential for development of standards and guidelines concerning the use and management of building materials [3,4].

In Lao PDR as in many other developing countries, cement is also an important construction material for house and building. It is used for general concrete work and blocks manufacturing as well as for plastering the building wall, which made of bricks. However, detailed information of the specific activities of ${ }^{226} \mathrm{Ra},{ }^{232} \mathrm{Th}$ and ${ }^{40} \mathrm{~K}$ in cement products and its raw materials in Lao PDR is not yet studied and is not available so far. This study is a continuation of our ongoing project related to the measurement of specific activity of ${ }^{238} \mathrm{U}\left({ }^{226} \mathrm{Ra}\right),{ }^{232} \mathrm{Th}$ and ${ }^{40} \mathrm{~K}$ in Lao building materials using gamma-ray spectrometric technique and estimation of the gamma dose rate from these radionuclides.

In this study, two common types of cement (portland and mixed) manufactured by 4 famous cement companies in Lao PDR were collected and their natural specific activities have been determined. These data were used for evaluating the potential radiological hazards associated to that materials by determining the radium equivalent activity $\left(\mathrm{Ra}_{e q}\right)$, the gamma-index $\left(\mathrm{I}_{\gamma}\right)$, Annual Effective Dose Equivalent (AEDE), Absorb Dose Rate in Air (D) and the external $\mathrm{H}_{e x}$ and internal $\mathrm{H}_{\text {in }}$ hazard indices. The results were compared with the corresponding reported values of cements of different countries.

\section{MATERIALS AND METHODS}

\section{II.1. Samples}

In this research, a total of 80 samples of two types of cement were collected from 4 local famous cement factories in Lao PDR. The name of cement companies, the type of cements used for investigation and their symbols are presented in Table 1.

The samples, each about $0.4 \mathrm{~kg}$ in weight, were dried in a temperature controlled furnace at $110^{\circ} \mathrm{C}$ for 24 hours to ensure that moisture was completely removed. After moisture removal, these samples were cooled in moisture-free atmosphere and pulverized into powdered form. After that the powdered samples were stored in tight plastic cylindrical containers (fit well to the volume 
Table 1. The name of cement companies, the type of cements used for investigation and their symbols.

\begin{tabular}{|l|l|l|}
\hline Name of cement company & Type of cement & Symbol \\
\hline \multirow{2}{*}{ VangVieng Cement plant.II } & Portland cement & $1 \mathrm{~V}$ \\
\cline { 2 - 3 } & Mixed cement & $2 \mathrm{~V}$ \\
\hline \multirow{2}{*}{ BMC Cement factory Golden Elephant-Laos } & Portland cement & $1 \mathrm{VT}$ \\
\cline { 2 - 3 } & Mixed cement & $2 \mathrm{VT}$ \\
\hline \multirow{2}{*}{ Lao Cement Industry.co., (Golden Elephant) } & Portland cement & $1 \mathrm{SV}$ \\
\cline { 2 - 3 } & Mixed cement & $2 \mathrm{SV}$ \\
\hline \multirow{2}{*}{ Lao Cement Industry.co.,LTD } & Portland cement & $1 \mathrm{~K}$ \\
\cline { 2 - 3 } & Mixed cement & $2 \mathrm{~K}$ \\
\hline
\end{tabular}

of our detector) for 4 weeks to reach secular equilibrium between ${ }^{226} \mathrm{Ra}$ and ${ }^{222} \mathrm{Rn}$ and their decay products.

\section{II.2. Natural radioactivity measurements}

The radioactivity concentrations of radionuclides in collected cement samples were determined by a high resolution gamma-ray spectrometry using a coaxial cylinder n-type high purity germanium (HPGe) detector model No.GEM20P4-70 of ORTEC company with an efficiency of $20 \%$ relative to a 3" 33 " $\mathrm{NaI}(\mathrm{Tl})$ scintillator detector. The energy resolution (FWHM) of the gamma-ray spectrometer is about $1.8 \mathrm{KeV}$ at energy peak of $1.33 \mathrm{MeV}$ of ${ }^{60} \mathrm{Co}$ isotope, and a peak-to-Compton ratio of 55:1. The detector was connected to a spectroscopy amplifier model 572A (ORTEC) and a computer based PCA-MR 8192 ACCUSPEC multi-channel analyzer. The MAESTRO-32 multi-channel analyzer emulation software was used for data acquisition, storage, display, online and off-line analysis of the gamma-spectra [5].

To prevent high background counts due to external radioactive sources, with the intention to reduce the counting time and improve the detection limit, the detector is placed in a lowlevel Canberra Model 747 lead shield having a thickness of $10 \mathrm{~cm}$. The inner part of the lead shield is covered with copper to reduce KXrays from lead.

Energy calibration of the detector was carried out by using two different sources ${ }^{60} \mathrm{Co}$ and ${ }^{226} \mathrm{Ra}$, which emit gamma-rays of energy ranged between $186.21 \mathrm{keV}$ and $2447.86 \mathrm{keV}$.

For the activity measurements, the samples were counted for a sufficiently long time in order to obtain a good statistics. Each sample was measured for about 72,000.0 s. Measurements with an empty sample container under identical conditions, were also carried out to determine the ambient background in the laboratory site.

The specific radioactivity of ${ }^{40} \mathrm{~K}$ was determined directly by its own gamma-ray at 1460.8 $\mathrm{keV}(10.7 \%)$, while the specific activities of ${ }^{226} \mathrm{Ra}$ and ${ }^{232} \mathrm{Th}$ were calculated based on the weighted mean value of their respective decay products in equilibrium. The specific radioactivity of ${ }^{226} \mathrm{Ra}$ was determined using the $295.22 \mathrm{keV}(18.5 \%), 351.93 \mathrm{keV}(35.6 \%)$ gamma-rays from ${ }^{214} \mathrm{~Pb}$ and $609.31 \mathrm{keV}$ (45.49\%), $768.36 \mathrm{keV}(4.89 \%) 1120.14 \mathrm{keV}(15.0 \%), 1764.43 \mathrm{keV}(15.28 \%)$ from ${ }^{214} \mathrm{Bi}$. The specific radioactivity of ${ }^{232} \mathrm{Th}$ was determined using the $583.187 \mathrm{keV}(85.0 \%)$, the $2614.511 \mathrm{keV}(99.79 \%)$ from ${ }^{208} \mathrm{Tl}$ and $911.12 \mathrm{keV}$ (25.8\%) from ${ }^{228} \mathrm{Ac}$ [6]. The value written inside the parentheses following gamma-ray energy indicates the absolute emission probability of 
the gamma decay. The activity concentrations in each sample were determined by relative method using the IAEA-RGU-1, IAEA-RGTh-1 and IAEA-RGK-1 reference materials, obtained from the International Atomic Energy Agency (IAEA), for which the radioactivity concentrations of the interested radioactive nuclides are known. The densities of the reference and investigated cement samples are similar. Furthermore, the geometry of the containers of cement samples was identical to that of the reference materials (IAEA-RGU-1, IAEA-RGTh-1 and IAEA-RGK-1). The following equation has been used for calculating the specific activity of ${ }^{40} \mathrm{~K},{ }^{226} \mathrm{Ra}$ and ${ }^{232} \mathrm{Th}$ radionuclides:

$$
A_{m}=\frac{C_{m}}{C_{s}} \times \frac{M_{S}}{M_{m}} \times A_{s} \times \frac{1-e^{-0.693 t_{m} / T_{1 / 2, i}}}{1-e^{-0.693 t_{s} / T_{1 / 2, i}}}
$$

where:

$A_{m}$ is the activity concentration of radionuclide in the cement sample given in $\mathrm{Bq} \mathrm{kg}^{-1}$;

$A_{s}$ is the activity concentration of radionuclide in the standard given in $\mathrm{Bq} \mathrm{kg}^{-1}$;

$C_{m}$ is the count rate obtained under the corresponding peak of cement sample ( $\left.\mathrm{s}^{-1}\right)$;

$C_{S}$ is the count rate obtained under the corresponding peak of standard sample $\left(\mathrm{s}^{-1}\right)$;

$M_{s}$ is mass of the standard sample in $\mathrm{kg}$;

$M_{m}$ is mass of cement sample in $\mathrm{kg}$;

$t_{m}$ is the measuring live time for the cement sample (s);

$t_{s}$ is the measuring live time for the standard sample (s);

$T_{1 / 2, i}$ is the half life of radioactive nuclide.

\section{II.3. Assessment of radiation hazard from Lao PDR cement}

In our study, the radiological parameters such as the radium equivalent activity $\left(\operatorname{Ra}_{e q}\right)$, the gamma index, the absorbed dose rate in air (D), the annual effective dose equivalent (AEDE), the external and internal hazard index $\left(\mathrm{H}_{e x}\right.$ and $\left.\mathrm{H}_{i n}\right)$ have been determined to assess the radiation hazards associated with Lao PDR cement samples.

\section{Radium equivalent activity $\left(\mathbf{R} \mathbf{a}_{e q}\right)$}

The most widely used radiation hazard index is called the radium equivalent activity [7] $\mathrm{Ra}_{e q}$ which is a weighted sum of activities of the 3 radionuclides ${ }^{226} \mathrm{Ra},{ }^{232} \mathrm{Th}$ and ${ }^{40} \mathrm{~K}$ based on following equation:

$$
R a_{e q}=A_{R a}+\left(\frac{10}{7}\right) A_{T h}+\left(\frac{10}{130}\right) A_{K}
$$

where $A_{R a}, A_{T h}$ and $A_{k}$ are the specific activities of ${ }^{226} \mathrm{Ra},{ }^{232} \mathrm{Th}$, and ${ }^{40} \mathrm{~K}$ in $\mathrm{Bq} \mathrm{kg}^{-1}$, respectively. In the definition of $\mathrm{Ra}_{e q}$, it is assumed that $370 \mathrm{~Bq} \mathrm{~kg}^{-1}$ of ${ }^{226} \mathrm{Ra}, 259 \mathrm{~Bq} \mathrm{~kg}^{-1}$ of ${ }^{232} \mathrm{Th}$ and 4810 $\mathrm{Bq} \mathrm{kg}^{-1}$ of ${ }^{40} \mathrm{~K}$ produce the same gamma-ray dose rate. The permissible maximum value of the radium equivalent activity is $370 \mathrm{~Bq} \mathrm{~kg}$-1 which corresponds to effective dose of $1 \mathrm{mSv}$ for the general public and to the radiation dose rate of $1.5 \mathrm{mGy} \mathrm{y}^{-1}[2,8]$.

Gamma-index $\left(I_{\gamma}\right)$ and alpha-index $\left(I_{\alpha}\right)$

The activity concentration index $I_{\gamma}$ (gamma index) was proposed by several investigators for identifying whether the European Commission guidelines about building material usage are met. In this study, the gamma-index was calculated as proposed by the European Commission 
$[1,9-11,13]$ as follows:

$$
I_{\gamma}=\frac{A_{R a}}{300}+\frac{A_{T h}}{200}+\frac{A_{K}}{3000}
$$

where $A_{R a}, A_{T h}$ and $A_{K}$ are the specific activities of ${ }^{226} \mathrm{Ra},{ }^{232} \mathrm{Th}$ and ${ }^{40} \mathrm{~K}$ in $\mathrm{Bq} \mathrm{kg}{ }^{-1}$, respectively. The case of $I_{\gamma} \leq 1$ corresponds to an absorbed gamma dose rate less or equal to $1 \mathrm{mSv} \mathrm{y}^{-1}$, while $I_{\gamma} \leq 0.5$ corresponds to a dose rate criterion of $0.3 \mathrm{mSv} \mathrm{y}^{-1}$. Thus the material with $I_{\gamma}>6$ should be avoided to use as building material because this value corresponds to the dose rate higher than $1 \mathrm{mSv} \mathrm{y}^{-1}$ which is the highest recommended values [12,18]. Due to radon inhalation originated from building material [19], the alpha index was proposed and it is determined using the following formula:

$$
I_{\alpha}=\frac{A_{R a}}{200\left(B q k g^{-1}\right)}
$$

where $\mathrm{A}_{R a}$ is the specify activity concentration of ${ }^{226} \mathrm{Ra}$ assumed in equilibrium with ${ }^{238} \mathrm{U}$. If $I_{\alpha}$ is less than 1 the cement is safe for building construction. This condition corresponds to the ${ }^{226} \mathrm{Ra}$ concentration being less than $200 \mathrm{~Bq} \mathrm{~kg}^{-1}$. As suggested by many countries in the world [20], the recommended exemption level and the recommended upper level for ${ }^{226} \mathrm{Ra}$ activity concentration in building materials are $100 \mathrm{~Bq} \mathrm{~kg}^{-1}\left(I_{\alpha}=0.5\right)$ and $200 \mathrm{~Bq} \mathrm{~kg}^{-1},\left(I_{\alpha}=1.0\right)$, respectively.

\section{Absorbed Dose Rate in Air D}

In order to assess any radiological hazard, the exposure to radiation arising from radionuclides present in cement can be determined in terms of many parameters. A direct connection between radioactivity concentrations of natural radionuclides and their exposure is known as the absorbed dose rate in the air at 1 metre above the ground surface. The mean activity concentrations of ${ }^{226} \mathrm{Ra}$ (of the ${ }^{238} \mathrm{U}$ series), ${ }^{232} \mathrm{Th}$ and ${ }^{40} \mathrm{~K}$ in $\mathrm{Bq} \mathrm{kg}{ }^{-1}$ in the cement samples are used to calculate the absorbed dose rate using a formula provided by UNSCEAR [2] and European Commission [12] as follows:

$$
D=0.92 A_{R a}+1.1 A_{T h}+0.08 A_{K}
$$

where $D$ is the absorbed dose rate in $\mathrm{nGy} \mathrm{h}^{-1}, A_{R a}, A_{T h}$ and $A_{k}$ are the activity concentration of ${ }^{226} \mathrm{Ra}\left({ }^{238} \mathrm{U}\right),{ }^{232} \mathrm{Th}$ and ${ }^{40} \mathrm{~K}$, respectively. The dose coefficients in units of $\mathrm{nGy} \mathrm{h}^{-1}$ per Bq kg${ }^{-1}$ were taken from the UNSEAR (2000) report $[2,8]$.

\section{Annual Effective Dose Equivalent (AEDE)}

The calculations of effective dose equivalent depend on the value of the absorbed dose rate in air. To accomplish these calculations, account must be taken of the conversion coefficient from absorbed dose rate in air to effective dose equivalent received by adult and occupancy fraction. The values of these two parameters vary depending on the climate at the area considered and the average age of the population. In the UNSCEAR 2008 report, the value of conversion coefficient was $0.7 \mathrm{~Sv} \mathrm{~Gy}^{-1}$ for male and female and to the indoor and outdoor, and the 0.2 for the outdoor occupancy fraction. Therefore, the outdoor annual effective dose equivalent can be calculated by the following formula $[2,14]$ :

$$
A E D E\left(\mu S v \cdot y^{-1}\right)=D(n G y \cdot h-1) \times 8760 h \times 0.8 \times 0.7 S v \cdot G y^{-1} \times 10^{-6}
$$


where, $D\left(\mathrm{nGy} \mathrm{h}^{-1}\right)$ is the total absorbed dose rate due to gamma radiations from materials containing radionuclides of ${ }^{226} \mathrm{Ra},{ }^{232} \mathrm{Th}$, and $0.7 \mathrm{SvG} \mathrm{y}^{-1}$ is the conversion coefficient from absorbed dose in air to effective dose.

\section{External and internal Hazard Indexes $\left(H_{e x}\right.$ and $\left.H_{i n}\right)$}

To limit the radiation exposure which is attributable to natural radionuclides in the cement samples to the permissible dose equivalent limit of $1 \mathrm{mSv} \mathrm{y}^{-1}$, the external hazard index has been introduced using a model proposed by Krieger [9] which is given as follows [2,15]:

$$
H_{e x}=\frac{A_{R a}}{370}+\frac{A_{T h}}{259}+\frac{A_{K}}{4810}
$$

In order to keep the radiation hazard insignificant, the value of external hazard index must not exceed the limit of unity. The maximum value of $\mathrm{H}_{e x}$ equal to unity corresponds to the upper limit of radium equivalent activity of $370 \mathrm{~Bq} \mathrm{~kg}^{-1}[9,16]$.

In addition to the external hazard, radon and its short-lived products are also hazardous to the repository organs. To account for this threat the maximum permissible concentration for ${ }^{226} \mathrm{Ra}$ must be reduced to half of the normal limit $\left(185 \mathrm{~Bq} \mathrm{~kg}^{-1}\right)$. The internal exposure to radon and its daughter progenies is quantified by the internal hazard index $\left(\mathrm{H}_{i n}\right)$ which is given by the following expression [17]:

$$
H_{i n}=\frac{A_{R a}}{185}+\frac{A_{T h}}{259}+\frac{A_{K}}{4810}
$$

The values of the indexes $\mathrm{H}_{e x}$ and $\mathrm{H}_{\text {in }}$ must be less than unity for radiation hazard to be negligible.

\section{RESULTS AND DISCUSSIONS}

The range and the mean specific radioactivity values of ${ }^{226} \mathrm{Ra},{ }^{232} \mathrm{Th}$ and ${ }^{40} \mathrm{~K}$ together with standard deviation as well as radium equivalent activity in two cement types produced by 4 local famous cement factories in Lao PDR are presented in Table 2. For each symbol, five identical cement samples were measured and the mean value of specific radioactivity was determined by averaging the specific radioactivity values of these same samples.

The specific activity concentrations in the investigated cement types used in Lao PDR were found to vary from $24.83 \pm 1.18$ to $54.39 \pm 5.90 \mathrm{~Bq} \mathrm{~kg}^{-1}$ for ${ }^{226} \mathrm{Ra}$; $6.63 \pm 1.59$ to $21.17 \pm$ $0.48 \mathrm{~Bq} \mathrm{~kg}^{-1}$ for ${ }^{232} \mathrm{Th}$ and $43.28 \pm 7.68$ to $168.70 \pm 3.34$ for ${ }^{40} \mathrm{~K}$, respectively. While the lowest activity concentration of ${ }^{226} \mathrm{Ra}$ was observed in $2 \mathrm{~K}$ (Mixed cement) cement sample, the highest value was in $1 \mathrm{SV}$ (Portland cement) one. For ${ }^{232} \mathrm{Th}$, the minimum value was in $2 \mathrm{SV}$ (Mixed cement) and maximum was found in 2VT (Portland cement). For the case of ${ }^{40} \mathrm{~K}$, the 2SV (Mixed cement) samples showed the lowest concentration, whereas 2VT (Portland cement) samples showed the highest concentrations. As can be seen from Table 2, the specific activity values of ${ }^{226} \mathrm{Ra},{ }^{232} \mathrm{Th}$ and ${ }^{40} \mathrm{~K}$ determined in cements of Lao PDR varied from one sample to another. These variations in activity concentration of ${ }^{226} \mathrm{Ra},{ }^{232} \mathrm{Th}$ and ${ }^{40} \mathrm{~K}$ in the investigated cement types used in Lao PDR may depend on the ${ }^{226} \mathrm{Ra},{ }^{232} \mathrm{Th}$ and ${ }^{40} \mathrm{~K}$ content under the earth crust from where the raw materials for particular brand of cement were made.

The mean specific activities of ${ }^{232} \mathrm{Th}$ and ${ }^{40} \mathrm{~K}$ obtained for the different brands of Lao PDR cement were less than the average worldwide values of 45 and $412 \mathrm{~Bq} \mathrm{~kg}^{-1}$ for ${ }^{232} \mathrm{Th}$ and ${ }^{40} \mathrm{~K}$ 
respectively, whereas the mean concentration of ${ }^{226} \mathrm{Ra}$ values observed in $1 \mathrm{~V}, 2 \mathrm{~V} 1,1 \mathrm{VT}, 1 \mathrm{SV}$ and $2 \mathrm{SV}$ cement type were higher than its corresponding mean worldwide value of $32 \mathrm{~Bq} \mathrm{~kg}^{-1}$.

Table 2. The ranges and the average activity concentration of ${ }^{40} \mathrm{~K},{ }^{238} \mathrm{U}$ and ${ }^{232} \mathrm{Th}$ and radium equivalent activity for the assessed cement samples.

\begin{tabular}{|c|c|c|c|c|c|c|c|}
\hline \multirow{3}{*}{$\begin{array}{r}\text { Sample } \\
\text { symbol } \\
\text { and type } \\
\text { of cement }\end{array}$} & \multicolumn{6}{|c|}{ Specific radioactivity $\left(\mathrm{Bq} \mathrm{kg}^{-1}\right)$} & \multirow{3}{*}{$\begin{array}{r}\mathrm{Ra}_{e q} \\
(\mathrm{~Bq} / \mathrm{kg})\end{array}$} \\
\hline & \multicolumn{2}{|c|}{${ }^{238} \mathrm{U}\left({ }^{226} \mathrm{Ra}\right)$} & \multicolumn{2}{|c|}{${ }^{232} \mathrm{Th}$} & \multicolumn{2}{|c|}{${ }^{40} \mathrm{~K}$} & \\
\hline & Range & Mean & Range & Mean & Range & Mean & \\
\hline $1 \mathrm{~V}$ & 36.88 & 39.88 & 8.61 & 10.10 & 137.85 & 156.92 & 66.38 \\
\hline Portland & -42.65 & \pm 2.19 & -11.16 & \pm 0.93 & -170.19 & \pm 10.94 & \pm 2.35 \\
\hline $2 \mathrm{~V}$ & 30.68 & 38.83 & 7.83 & 9.67 & 83.14 & 126.99 & 62.41 \\
\hline Mixed & -43.60 & \pm 4.91 & -12.30 & \pm 1.57 & -146.99 & \pm 22.07 & \pm 5.20 \\
\hline $1 \mathrm{VT}$ & 32.20 & 33.57 & 16.35 & 17.37 & 127.55 & 131.93 & 68.56 \\
\hline Portland & -36.04 & \pm 2.14 & -18.12 & \pm 0.92 & -136.73 & \pm 4.60 & \pm 2.17 \\
\hline $2 \mathrm{VT}$ & 29.28 & 30.32 & 20.50 & 21.17 & 165.73 & 168.70 & 73.54 \\
\hline Mixed & -31.65 & \pm 1.16 & -21.65 & \pm 0.48 & -173.38 & \pm 3.34 & \pm 1.19 \\
\hline $1 \mathrm{SV}$ & 47.45 & 54.39 & 6.77 & 7.91 & 43.46 & 45.22 & 69.17 \\
\hline Portland & -60.19 & \pm 5.90 & -8.94 & \pm 0.97 & -46.74 & \pm 1.41 & \pm 5.90 \\
\hline $2 \mathrm{SV}$ & 47.69 & 51.74 & 5.19 & 6.63 & 33.12 & 43.28 & 64.54 \\
\hline Mixed & -58.26 & \pm 4.64 & -8.45 & \pm 1.59 & -51.71 & \pm 7.68 & \pm 4.68 \\
\hline $1 \mathrm{~K}$ & 25.02 & 28.55 & 20.39 & 20.73 & 135.98 & 141.83 & 69.07 \\
\hline Portland & -32.17 & \pm 3.13 & -21.64 & \pm 0.61 & -144.21 & \pm 3.94 & \pm 3.14 \\
\hline $2 \mathrm{~K}$ & 23.77 & 24.83 & 15.18 & 16.61 & 108.93 & 113.71 & 57.31 \\
\hline Mixed & -26.36 & \pm 1.18 & -17.52 & \pm 1.26 & -118.65 & \pm 4.71 & \pm 1.23 \\
\hline $\operatorname{Mean} \pm \mathbf{S D}$ & & 37.76 & & 13.77 & & 116.07 & 66.40 \\
\hline & & $\pm \mathbf{1 0 . 7 1}$ & & $\pm \mathbf{5 . 8 5}$ & & $\pm \mathbf{4 7 . 5 0}$ & \pm 4.96 \\
\hline
\end{tabular}

The distributions of ${ }^{226} \mathrm{Ra},{ }^{232} \mathrm{Th}$ and ${ }^{40} \mathrm{~K}$ in the cement samples are not uniform. Due to this non uniformity of natural radionuclides in the investigated cement samples, the radium equivalent activity $\left(\mathrm{Ra}_{e q}\right)$ was calculated to compare the specific activities of the studied cement samples and the results are summarized in table 2 as well. In all the cement samples, the $\mathrm{Ra}_{e q}$ values vary from 57.31 to $73.54 \mathrm{~Bq} \mathrm{~kg}^{-1}$ with a mean of $66.40 \pm 4.96 \mathrm{~Bq} \mathrm{~kg}^{-1}$. It is observed 
that the $\mathrm{Ra}_{e q}$ values for all the studied samples are lower than the recommended maximum value of $370 \mathrm{~Bq} \mathrm{~kg}^{-1}$, which corresponds to an annual effective dose of $1 \mathrm{mSv}$. Thus, these samples are within the recommended safety limit when they are used as building materials and products.

Table 3. Comparison between the average activity concentrations (in $\mathrm{Bq} \mathrm{kg}^{-1}$ ) of Lao PDR cement with those of some other countries in the world.

\begin{tabular}{|c|c|c|c|c|c|}
\hline \multirow{2}{*}{ Country } & \multicolumn{3}{|c|}{ Activity concentration $\left(\mathrm{Bq} \mathrm{kg}^{-1}\right)$} & \multirow{2}{*}{$\begin{array}{r}\mathrm{Ra}_{e q} \\
\left(\mathrm{~Bq} \mathrm{~kg}^{-1}\right)\end{array}$} & \multirow{2}{*}{ References } \\
\hline & ${ }^{226} \mathrm{Ra}$ & ${ }^{232} \mathrm{Th}$ & ${ }^{40} \mathrm{~K}$ & & \\
\hline Australia & 51.50 & 48.10 & 114.7 & 129.4 & [7] \\
\hline Turkey & 40 & 28.00 & 248.3 & 99.1 & [16] \\
\hline Ghana & 35.94 & 25.44 & 251.00 & 90.12 & [15] \\
\hline China & 56.50 & 36.50 & 173.2 & 122.0 & [21] \\
\hline Brazil & 61.70 & 58.50 & 564 & 188.80 & [22] \\
\hline Italy & 38.00 & 22.00 & 218 & 92 & [23] \\
\hline Turkey & 50 & 40 & 324 & $62-324$ & [19] \\
\hline Vietnam & 39.86 & 25.46 & 243.5 & & [24] \\
\hline Lao PDR & $\begin{array}{r}37.76 \\
\pm 10.71\end{array}$ & $\begin{array}{r}13.77 \\
\pm 5.85\end{array}$ & $\begin{array}{r}116.07 \\
\pm 47.50\end{array}$ & $\begin{array}{r}66.40 \\
\pm 4.96\end{array}$ & This work \\
\hline
\end{tabular}

The comparison of the value of ${ }^{226} \mathrm{Ra},{ }^{232} \mathrm{Th}$ and ${ }^{40} \mathrm{~K}$ and radium equivalent $\left(\mathrm{Ra}_{e q}\right)$ activities in the cement samples collected in Lao PDR with the same data of cements from other countries was made. In Table 3, the mean values of specific radioactivity of ${ }^{226} \mathrm{Ra},{ }^{232} \mathrm{Th},{ }^{40} \mathrm{~K}$ and $\mathrm{Ra}_{e q}$ determined for cement samples are compared with the corresponding values determined in other countries, all of the observed valued values of ${ }^{226} \mathrm{Ra},{ }^{232} \mathrm{Th},{ }^{40} \mathrm{~K}$ and $\mathrm{Ra}_{e q}$ were lower than the reported data of other countries.

Table 4 shows the following calculated parameters for the studied cement samples: indoor gamma dose rate $(D)$, annual effective dose equivalent (AEDE) from indoor terrestrial gamma radiation, internal $\left(\mathrm{H}_{i n}\right)$ and external $\left(\mathrm{H}_{e x}\right)$ hazard indices and the gamma activity index $\left(\mathrm{I}_{\gamma}\right)$ and alpha $\left(\mathrm{I}_{\alpha}\right)$. It can be seen from this table that the estimated indoor gamma dose rate $(D)$ values for the investigated cement samples range from 50.21 to $64.68 \mathrm{nGy} \mathrm{h}^{-1}$ with a mean of $59.18 \pm 4.37$ $\mathrm{nGy} \mathrm{h}^{-1}$. This mean value of indoor gamma dose rate of Lao PDR cement samples is lower than the word average (populated-weighted) indoor absorbed gamma dose rate of $84 \mathrm{nGy} \mathrm{h}^{-1}[2,13]$.

The annual effective dose equivalent (AEDE) from indoor terrestrial gamma radiation for the studied cement samples were calculated and presented in the third column of Table 4 . These values vary from 0.25 to $0.32 \mathrm{mSv} \mathrm{y}^{-1}$ with a mean of $0.29 \pm 0.02 \mathrm{mSv} \mathrm{y}^{-1}$. The concentration of Naturally Occurring Radioactive Materials (NORM) together with the radon exhalation rate, determines the total chronic (prolonged) radiation dose of building materials to the general public. 
It is noted that the average annual effective dose equivalent is about $79 \%$ less than the dose criterion $1 \mathrm{mSv} \mathrm{y}^{-1}[25]$.

The internal $\left(\mathrm{H}_{i n}\right)$ and external $\left(\mathrm{H}_{e x}\right)$ hazard indices for the investigated cement samples were estimated and presented in Table 3 . The internal $\left(\mathrm{H}_{i n}\right)$ hazard indices vary from 0.22 to 0.33 with a mean of $0.28 \pm 0.03$ while the internal external $\left(\mathrm{H}_{e x}\right)$ hazard indices vary from 0.15 to 0.20 with a mean of $0.18 \pm 0.02$. These indices are, less than unity as required by the above-mentioned index formulae, therefore these cements are regarded as safe for construction purposes.

To assess safety requirement for building materials, the gamma activity index $\left(\mathrm{I}_{\gamma}\right)$ and alpha activity index $\left(\mathrm{I}_{\alpha}\right)$ are used. They were evaluated and presented in Table 4 in the two last columns. The obtained values for the gamma activity index $\mathrm{I}_{\gamma}$ vary from 0.20 to 0.26 with a mean of 0.23 \pm 0.02 . The values of alpha activity index $\mathrm{I}_{\alpha}$ range from 0.12 to 0.27 with a mean of $0.19 \pm$ 0.05 . The obtained values of gamma activity indexes in all Lao PDR cement samples were within the exemption dose criterion $\left(0.3 \mathrm{mSv} \mathrm{y}^{-1}\right)$ and corresponds to an activity concentration index of $\mathrm{I}_{\gamma} \leq 0.5$ proposed for materials used in bulk construction [12]. The results obtained for alpha index in all studied cement samples are lower than the unity. This indicates that the radon exhalation from cement would cause indoor concentration less than $200 \mathrm{~Bq} \mathrm{~cm}^{-3}$.

Table 4. Value of Radiological Hazard Parameters of the investigated cement samples.

\begin{tabular}{|c|c|c|c|c|c|c|}
\hline $\begin{array}{c}\text { Sample } \\
\text { symbol and } \\
\text { type of cement }\end{array}$ & $\begin{array}{c}\mathrm{D} \\
\left(\mathrm{nGy} \mathrm{h}^{-1}\right)\end{array}$ & $\begin{array}{c}\mathrm{AEDE} \\
\left(\mathrm{mSv} \mathrm{y}^{-1}\right)\end{array}$ & $\mathrm{H}_{e x}$ & $\mathrm{H}_{i n}$ & $\mathrm{I}_{\gamma}$ & $\mathrm{I}_{\alpha}=1$ \\
\hline $\begin{array}{c}\mathbf{1 V} \\
\text { Portland }\end{array}$ & $60.35 \pm 2.42$ & $0.30 \pm 0.01$ & $0.18 \pm 0.01$ & $0.29 \pm 0.01$ & $0.24 \pm 0.01$ & $0.20 \pm 0.01$ \\
\hline $\begin{array}{c}\mathbf{2 V} \\
\text { Mixed }\end{array}$ & $56.52 \pm 5.15$ & $0.28 \pm 0.03$ & $0.17 \pm 0.02$ & $0.27 \pm 0.03$ & $0.22 \pm 0.02$ & $0.19 \pm 0.02$ \\
\hline $\begin{array}{c}\text { 1VT } \\
\text { Portland }\end{array}$ & $60.57 \pm 2.24$ & $0.30 \pm 0.0$ & $0.19 \pm 0.01$ & $0.28 \pm 0.01$ & $0.24 \pm 0.01$ & $0.17 \pm 0.01$ \\
\hline $\begin{array}{c}\mathbf{2 V T} \\
\text { Mixed }\end{array}$ & $64.68 \pm 1.22$ & $0.32 \pm 0.01$ & $0.20 \pm 0.01$ & $0.28 \pm 0.01$ & $0.26 \pm 0.01$ & $0.15 \pm 0.01$ \\
\hline $\begin{array}{c}\text { 1SV } \\
\text { Portland }\end{array}$ & $62.36 \pm 5.53$ & $0.31 \pm 0.03$ & $0.19 \pm 0.02$ & $0.33 \pm 0.03$ & $0.24 \pm 0.02$ & $0.27 \pm 0.03$ \\
\hline $\begin{array}{c}\mathbf{2 S V} \\
\text { Mixed }\end{array}$ & $58.36 \pm 4.65$ & $0.29 \pm 0.02$ & $0.17 \pm 0.01$ & $0.31 \pm 0.03$ & $0.22 \pm 0.02$ & $0.26 \pm 0.02$ \\
\hline $\begin{array}{c}\text { 1K } \\
\text { Portland }\end{array}$ & $60.42 \pm 2.97$ & $0.30 \pm 0.01$ & $0.19 \pm 0.01$ & $0.26 \pm 0.02$ & $0.25 \pm 0.01$ & $0.14 \pm 0.02$ \\
\hline $\begin{array}{c}\text { 2K } \\
\text { Mixed }\end{array}$ & $50.21 \pm 1.80$ & $0.25 \pm 0.01$ & $0.15 \pm 0.01$ & $0.22 \pm 0.01$ & $0.20 \pm 0.01$ & $0.12 \pm 0.01$ \\
\hline \begin{tabular}{c} 
Mean \pm SD \\
\hline
\end{tabular} & $59.18 \pm 4.37$ & $0.29 \pm 0.02$ & $0.18 \pm 0.02$ & $0.28 \pm 0.03$ & $0.23 \pm 0.02$ & $0.19 \pm 0.05$ \\
\hline
\end{tabular}




\section{CONCLUSIONS}

The natural radioactivity due to the presence of ${ }^{226} \mathrm{Ra},{ }^{232} \mathrm{Th}$ and ${ }^{40} \mathrm{~K}$ radionuclides in Lao PDR cements was measured for the first time using a gamma-spectrometry with HPGe detector. Two different types of cement produced by 4 local cement companies in Lao PDR have been investigated. The average activity concentrations of the calculated and the observed mean activity concentrations of ${ }^{232} \mathrm{Th}$ and ${ }^{40} \mathrm{~K}$ are comparably lower than the typical world mean activity of 42 and $420 \mathrm{~Bq} \mathrm{~kg}^{-1}$. However the mean specific activity values of ${ }^{226} \mathrm{Ra}$ were lower than the world average value of $32 \mathrm{~Bq} \mathrm{~kg}^{-1}$ with the exception of the observed values in $1 \mathrm{~V}, 2 \mathrm{~V}, 1 \mathrm{VT}, 1 \mathrm{SV}$ and $2 \mathrm{SV}$ cement type which were relatively higher than the recommended average value.

The specific radioactivity of ${ }^{226} \mathrm{Ra},{ }^{232} \mathrm{Th}$ and ${ }^{40} \mathrm{~K}$ in the investigated samples ranged from $24.83 \pm 1.18$ to $54.39 \pm 5.90 \mathrm{~Bq} \mathrm{~kg}^{-1}$ with a mean of $37.76 \pm 10.71 \mathrm{~Bq} \mathrm{~kg}^{-1}, 6.63 \pm 1.59$ to $21.17 \pm 0.48 \mathrm{~Bq} \mathrm{~kg}^{-1}$ with a mean of $13.77 \pm 5.85 \mathrm{~Bq} \mathrm{~kg}^{-1}$ and $43.28 \pm 7.68$ to 168.70 $\pm 3.34 \mathrm{~Bq} \mathrm{~kg}^{-1}$ with a mean of $116.07 \pm 47.50 \mathrm{~Bq} \mathrm{~kg}^{-1}$, respectively. The radium equivalent activity $\left(\mathrm{Ra}_{e q}\right)$, the gamma-index, the external and internal hazard indices, Absorb Dose Rate in Air (D) and Annual Effective Dose Equivalent (AEDE) were estimated for the radiation hazard of the natural radioactivity in all cement samples. The obtained results were compared with the corresponding values for cement of different countries. The calculated $\mathrm{Ra}_{e q}$ value $(66.40 \pm 4.96$ $\mathrm{Bq} \mathrm{kg}^{-1}$ ) of Lao PDR samples are lower than the limit of $370 \mathrm{~Bq} \mathrm{~kg}^{-1}$ set for building materials. The mean indoor absorbed dose rate is slightly lower than the population-weighted average of 84 $\mathrm{nGy} \mathrm{h}^{-1}$ while the corresponding effective dose was $79 \%$ less than the dose criterion of $1 \mathrm{mSv} \mathrm{y}^{-1}$. The results obtained in this study show no significant radiological hazards arising from using Lao PDR cement for construction of houses.

\section{ACKNOWLEDGMENTS}

This work was supported in part by the Institute of Physics, Vietnam Academy of Science and Technology.

\section{REFERENCES}

[1] M. Markkanen, Report STUK-B-STO 32, Radiation and Nuclear Safety Authority - STUK (1995).

[2] UNSCEAR, Report to General Assembly, Vol. 1, Annex B, United Nations, New York (2000).

[3] S. Turhan and G. Gürbüz, Radiat. Prot. Dosim. 129 (2008) 391.

[4] S. A. Mujahid, A. Rahim, S. Hussain and M. Farooq, Radiat. Prot. Dosim. 130 (2008) 206.

[5] MAESTRO,www.ortec-online.com/download/MAESTRO.pdf.

[6] Gordon Gilmore, Practical Gamma-Ray Spectrometry, John Wiley \& Sons Ltd. (2008)

[7] J. Beretka and P. J. Mathew, Health Phys. 48 (1985) 87.

[8] B. Wassila and B. Ahmed, J. Environ. Radioac. 102 (2011) 336.

[9] V. R. Krieger, Betonwerk Fertigteil Tech. 47 (1981) 468.

[10] E. M. Krisiuk, S. I. Tarasov, V. P. Shamov, N. I. Shalak, E. P. Lisachenko, L. G. Gomelsky, Research Institute for Radiation Hygiene, Leningrad (1971).

[11] E. Stranden, Physica Norvegica 8 (1976) 167.

[12] EC (European Commission), Radiation Protection 112 Directorate-General Environment, Nuclear Safety and Civil Protection (1999).

[13] UNSCEAR, Annex B: exposures of the public and workers from various sources of radiation, Report to the general assembly, United Nations, New York (2008).

[14] N. Damla, U. Cevik, A. I. Kobya, A. Celik, N. Celik, R. Van Grieken, J. Hazardous Materials 176 (2010) 644. 
[15] D. O. Kpeglo, H. Lawluvi, A. Faanu, A. R. Awudu, P. Deatanyah, S. G. Wotorchi, C. C. Arwui, G. Emi Reynolds and E. O. Darko, Research Journal of Environmental and Earth Sciences 3 (2011) 161.

[16] S. Turhan and L. Gundiz, J. Environ. Radioac. 99 (2008) 332.

[17] L. Xinwei, J. Radioanal. Nucl. Chem. 262 (2004) 775.

[18] H. Taskin, M. Karavus, P. Ay, A. Topuzoglu, S. Hindiroglu and G. Karahan, J. Environ. Radioac. 100 (2009) 49.

[19] S. Dragovic, L. Jankovic and A. Onjia, Radiat. Prot. Dosim. 121 (2006) 297.

[20] Radiation Protection Authorities (RPA) in Denmark, Finland, Iceland, Norway and Sweden, Naturally occurring Radiation in the Nordic countries-Recommendations (the flag-book series), (2000).

[21] L. Xinwei, Health Phys. 88 (2005) 84.

[22] A. Malanca, V. Pessina and G. Dallara, Radiat. Prot. Dosim. 48 (1993) 199.

[23] S. Rizzo, M. Brai, S. Basile, S. Bellia and S. Hauser, Appl. Radiat. Isot. 55 (2001) 259.

[24] Le Nu Sieu, Nguyen Thanh Binh, Truong Y, Nguyen Trong Ngo, Nguyen Thi Linh, Nguyen Van Phuc, Nguyen Dinh Tung, Nguyen Kim Thanh, Tran Dinh Khoa, In: Proceedings of WM2011 Conference, February 27 March 3, 2011, Phoenix, AZ

[25] International Atomic Energy Agency (IAEA), Safety Series No. 115, IAEA, Vienna (1996). 